\title{
COMPARATIVE ANALYSIS OF THE MAIN SOCIAL HEALTH DETERMINANTS OF LIFE EXPECTANCY AND INFANT MORTALITY IN UKRAINE AND POLAND
}

DOI: 10.36740/WLek202103235

\author{
Taras G. Gutor, Natalia I. Zaremba, Oksana R. Kovalska, Dzvenyslava Je. Moskviak-Lesniak, Iryna M. Gerasymovych', \\ Oleh Ja. Kobyletskyy, Yaryna V. Nahurna \\ DANYLO HALYTSKY LVIV NATIONAL MEDICAL UNIVERSITY, LVIV, UKRAINE
}

\begin{abstract}
The aim: To analyze the data of social health determinants - life expectancy of population and infant mortality in neighboring countries: Ukraine and Poland in cut-away of territory habitation.

Materials and methods: The statistical materials of the Ukrainian and Polish information sources were used in this work: SI"The center of medical statistics of the Ministry of Health of Ukraine", The state statistics service of Ukraine, The central statistical management of Poland (Główny Urząd Statystyczny). Methods of system approach, bibliosemantic, statistical, analytical were used for analysis.

Results: In both countries, Poland and Ukraine, the general dynamics as to the growth of an average life expectancy (ALE) among men and women was observed during 28 years of surveillance, and in both countries it was revealed that the ALE indices in women were much higher than in men. Within the last five years, there is a considerable tendency of decrease in the infant death rate in Ukraine, while in Poland this index is particularly invariable. This may be due to the fact that the level of infant mortality in Poland is half the level in Ukraine; moreover, this correlation is approximate within the last five years of observation. A significant place in the structure of all the causes of infant mortality in 2019 is occupied by the XVI chapter in accordance with ICD-10 "Certain conditions originating in the perinatal period" - 54.39\% in Ukraine and $53.05 \%$ in Poland, the last - "Diseases of the Urogenital system" (chapter XIV) - $0 \%$ and $0.7 \%$, correspondingly.

Conclusions: With a view of an incessant improvement of a high-quality information which is registered when the statistical data are formed, it is necessary to promote a broad intersector cooperation inside the countries and international collaboration between the countries.
\end{abstract}

KEY WORDS: health indices, regional peculiarities, children's mortality, causes of infant mortality

Wiad Lek. 2021;74(3 p.II):750-755

\section{INTRODUCTION}

The level of well-being of society is determined by the health status of the population, therefore, the information as to the health status of the population is the necessary base for taking the administrative decisions the health care organization and with the aim to control the morbidity rate.

According to the WHO data (strategy "Health 2020: the European policy for health and well-being" [1]) the main social health determinants are the infant mortality, the life expectancy, provision of primary education to children and the level of unemployment. The life expectancy and the infant mortality (under 1 year old) are the only ones among all the determinants that pertain to the health care organization, so let us dwell upon their analysis in detail.

The life expectancy in the European region increases, while the gap between the indices of men and women in the majority of countries, and exactly between the countries decreases. The average life expectancy at birth in the European region increases in men from 75.60 years in 2010 to 77.34 years in 2018 (average annual increase +0.22 years); in women: from 81.96 years to 83.04 years (average annual increase +0.13 years) respectively $[2,3]$.
Simultaneously, in the European region the significant decrease of the children's mortality level is observed. In 2015 , the infant mortality level was equal to 6.8 cases of death in 1000 live-born babies, while in 2020, this index has decreased almost twice -3.7 deaths per 1000 live-born babies $[2,3]$.

Ukraine and Poland are countries - neighbors (more than $500 \mathrm{~km}$ of common borders) with similar natural-climatic conditions and practically the same number of population: $41.732 \mathrm{mln}$. people (32nd place in the world) and $38.383 \mathrm{mln}$. people (35th place in the world) correspondingly. Both countries are highly urbanized. In Ukraine, the level of urbanization is equal to $70.1 \%$ of population, in Poland $-60.5 \%$ of population. But there are differences in this process. In Ukraine, the share of urban population increases per year: the growth rates $-0.35 \%$ (trend evaluation for 2015-2020). Whereas in Poland, the number of the urban population decreases, from year to year, and accordingly, the rural population increases: the share of urban depopulation rate is equal to $0.1 \%$.

Starting from the 1 of January, 2020 in Ukraine, among all 29719 population centers there are 461 towns (1.55\%), 


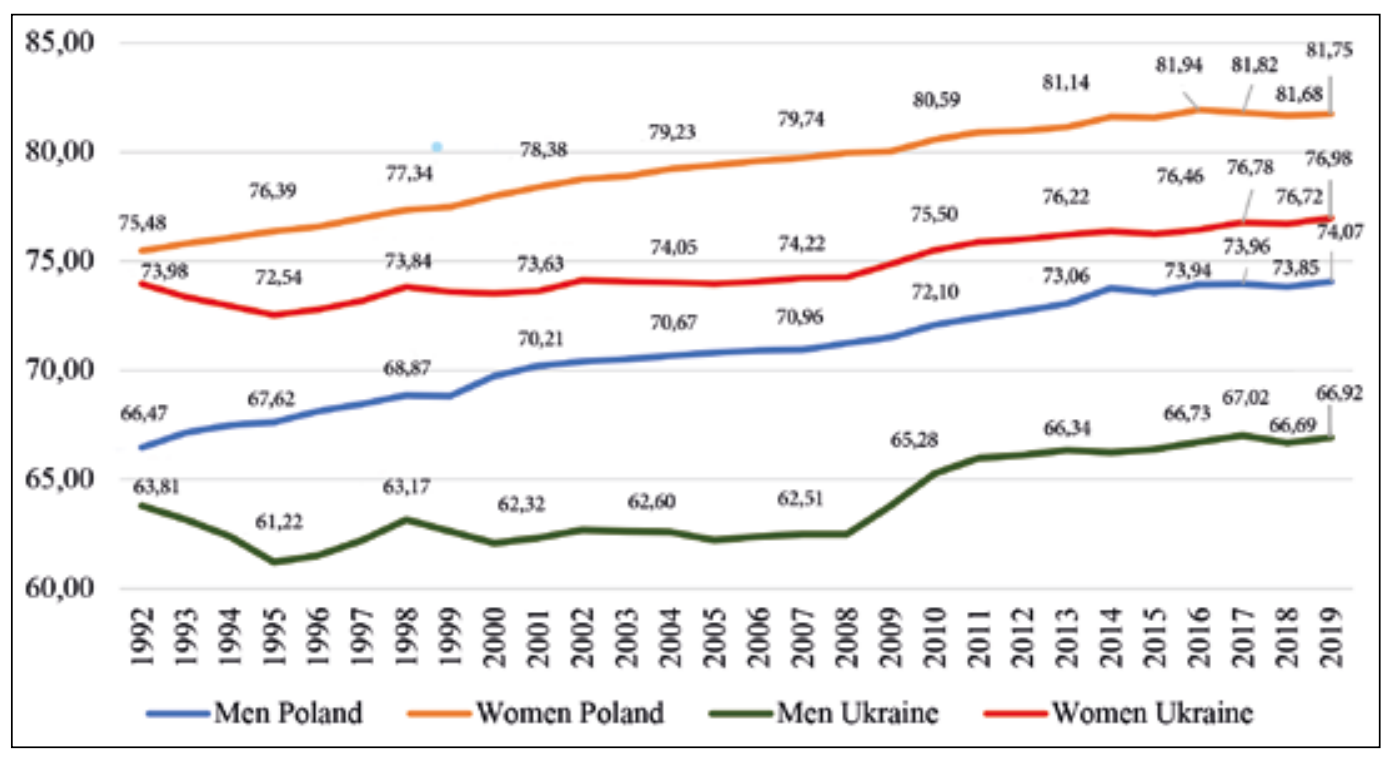

Fig. 1. Average life expectancy at birth (years) by gender in Ukraine and Poland in 19922019.

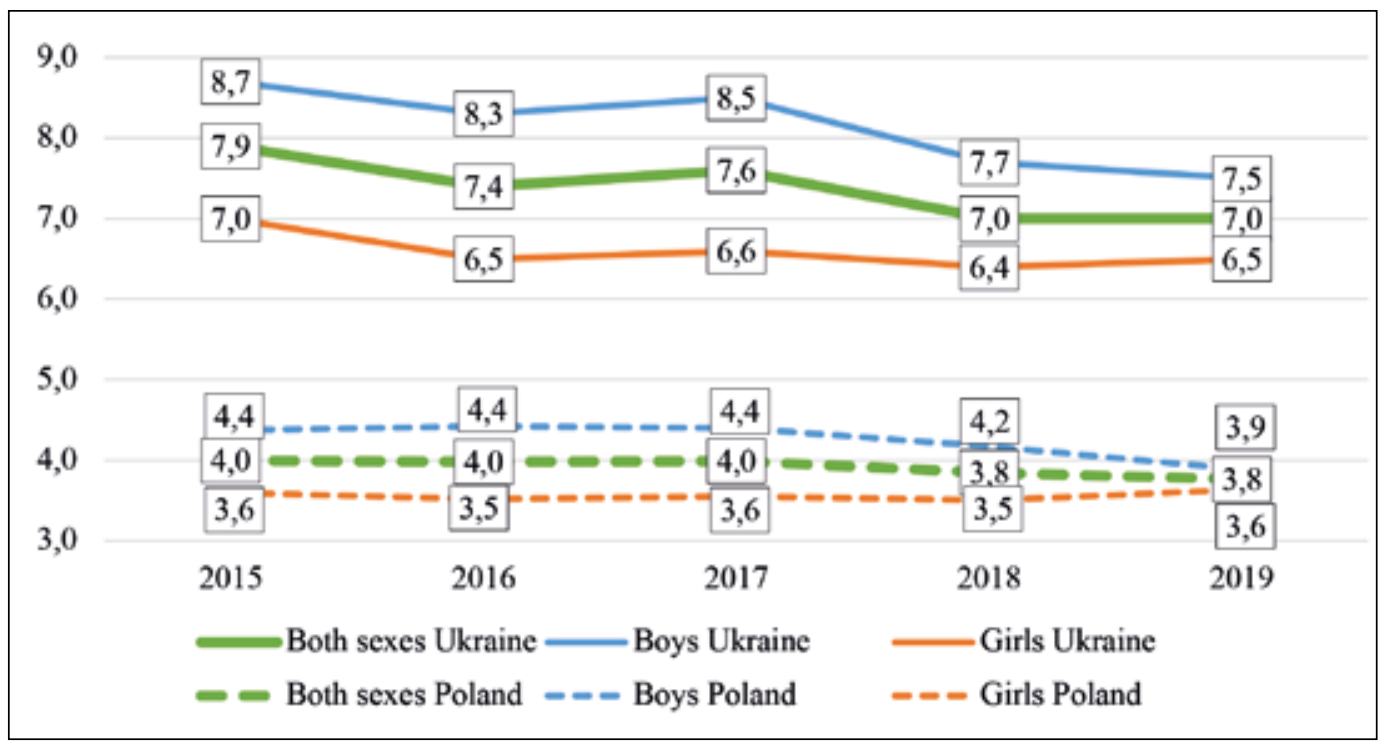

Fig. 2. Death rate of infants under 1 year old by gender in 2015-2019 in Ukraine and Poland (per 1000 live-born babies).
882 urban-type villages (2.97\%) and 28376 rural population centers (95.48\%). In Poland, there are only 44022 population centers, comprising: 930 towns $(2.11 \%), 13022$ urban-type villages (gminy miejsko-wiejskie - $29.58 \%$ ) and 30070 villages (gminy wiejskie $-68.31 \%$ ). Thereby, according to the absolute numbers, there is an approximate equal number of rural settlements in both countries, but as to the percentage ratio with other types of population centers, their number is much higher in Ukraine than in Poland.

\section{THE AIM}

To analyze the data of social health determinants - life expectancy of population and infant mortality in neighboring countries: Ukraine and Poland in cut-away of territory habitation.

\section{MATERIALS AND METHODS}

The statistical materials of the Ukrainian and Polish information sources were used in this work: The state statistics service of Ukraine [3], SI "The center of medical statistics of the Ministry of Health of Ukraine" [4], "The central statistical management of Poland" (Główny Urząd Statystyczny) [5]. Methods of system approach, bibliosemantic, statistical, analytical were used for analysis [6].

\section{REVIEW AND DISCUSSION}

The comparison of dynamics of the average life expectancy at birth (ALE) on the investigated territories within the period of 1992-2019 has shown the general dynamics of ALE growth in men and women in Poland and Ukraine during 28 years of observation. In Poland, identically as in Ukraine, the ALE indices are much higher in women than in men: from 75.48 years in 1992 to 81.75 years in 2019 . While the highest ALE level in the Polish men that was in 2019 (74.07 years) failed to reach the lowest ALE level in the Polish women in $1992-75.48$ years (fig. 1).

The comparison of data between the countries under study has shown that ALE indices in the Ukrainian women were higher than those in the Polish men, but lower than 

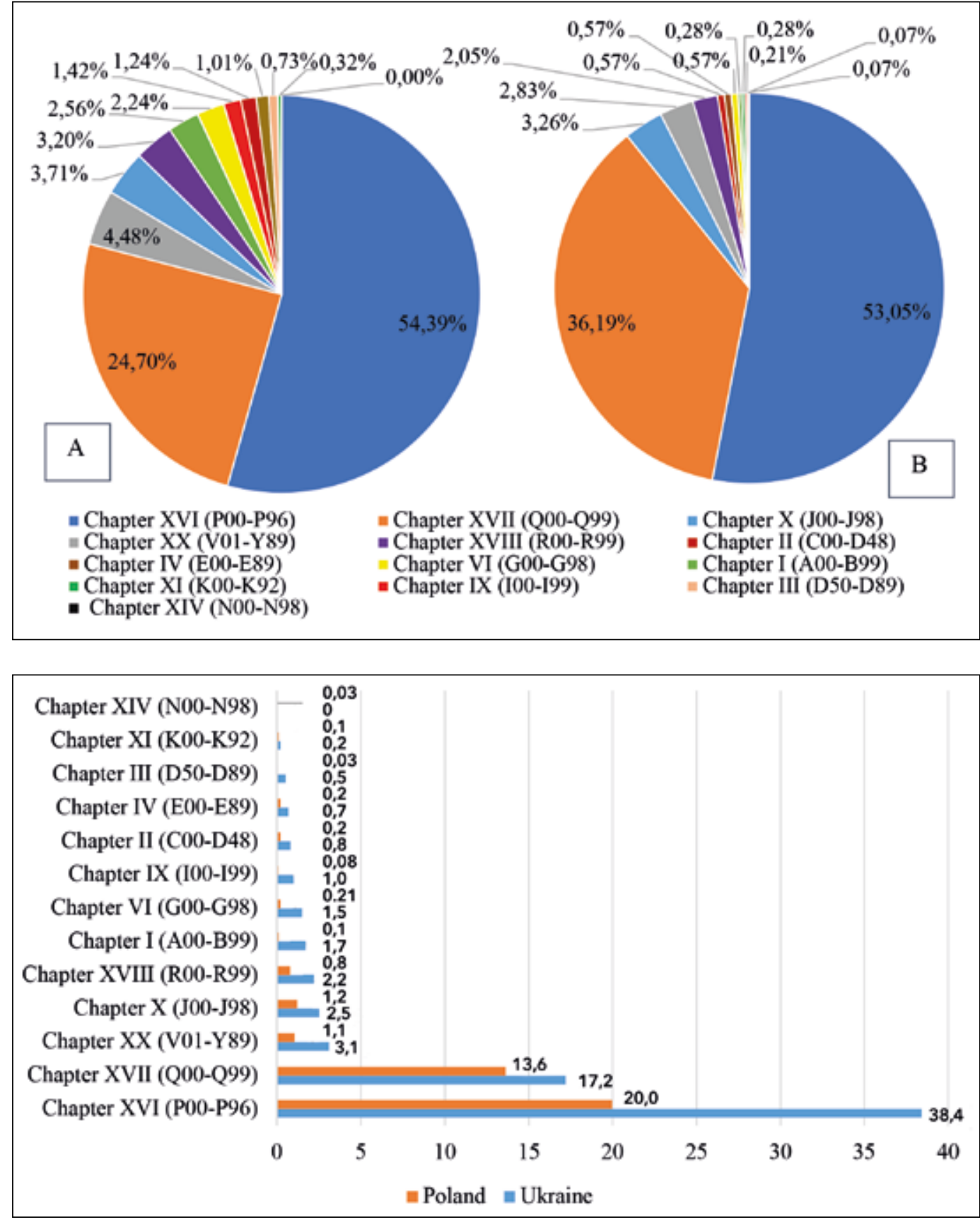

Fig. 3. Structure of causes of infant mortality (\%) in Ukraine (A) and Poland (B) in 2019
Fig. 4. Infant mortality levels (per 10 thousand of live-born babies) in Ukraine and Poland in 2019 the ALE indices in the Polish women. The least gap in years was in 1992 - merely 1.5 years, but over time this gap began to increase and in 2019 it was equal already to 4.77 years.

The level of the average life expectancy at birth in men from Ukraine was the lowest one with the minimal index in 1995 (61.22 years) and the maximal in 2017 (67.02 years).

The ALE analysis in men and women from 22 regions of Ukraine (the data from Donetsk and Lugansk regions, and the Autonomous Republic of Crimea are unavailable) has shown that the highest levels of this index is mainly in the Western regions of Ukraine: Ivano-Frankivsk, Chernivtsi, Ternopil, Lviv (table 1).

While the lowest ALE index was in the Northern and Central regions of Ukraine (Dnipropetrovsk region, Chernihiv region, Kirovohrad region, Zhytomyr region,
Kyiv region). Practically in all regions of Ukraine, the ALE level was higher in urban settlements (except Transcarpathian region). The largest difference in these indices among men was in Khmelnytskyi region (4.67 years) and Rivne region (3.93 years) and among women - in Odessa region ( 3.02 years) and Zhytomyr region ( 2.35 years). The lowest difference between the ALE indices in urban settlements and rural areas in men was in Kharkiv region (1.17 years) and Kirovohrad region (1.26 years); in women - in Kherson region ( 0.11 years) and Ivano-Frankivsk region (0.53 years).

On estimating the ALE level in 16 voivodeship of Poland, it was established that the lowest indices were in inhabitants of the center and west (Kuyavian-Pomeranian voivodeship, Lubusz voivodeship, Lodz voivodeship); while 
Table 1. Average life expectancy at birth (years) by gender and type of settlement in regions of Ukraine in 2019

\begin{tabular}{|c|c|c|c|c|c|c|c|}
\hline & \multirow{2}{*}{ Regions } & \multicolumn{2}{|c|}{ Urban settlements (C) } & \multicolumn{2}{|c|}{ Rural settlements (V) } & \multirow{2}{*}{$\begin{array}{l}\text { difference between } \\
C \text { and } V \text { in men }\end{array}$} & \multirow{2}{*}{$\begin{array}{l}\text { difference between } \\
C \text { and } V \text { in women }\end{array}$} \\
\hline & & m & f & m & f & & \\
\hline & Ukraine & 67.66 & 77.3 & 65.56 & 76.2 & 2.1 & 1.1 \\
\hline 1 & Vinnytsia & 68.96 & 78.36 & 66.13 & 76.7 & 2.83 & 1.66 \\
\hline 2 & Volyn & 68.05 & 77.79 & 64.96 & 76.75 & 3.09 & 1.04 \\
\hline 3 & Dnipropetrovsk & 66.11 & 76.25 & 64.68 & 74.44 & 1.43 & 1.81 \\
\hline 4 & Zhytomyr & 66.18 & 76.73 & 62.86 & 74.38 & 3.32 & 2.35 \\
\hline 5 & Transcarpathian & 66.52 & 75.06 & 67.17 & 75.25 & -0.65 & -0.19 \\
\hline 6 & Zaporizhia & 66.54 & 77.03 & 64.52 & 74.69 & 2.02 & 2.34 \\
\hline 7 & Ivano-Frankivsk & 70.71 & 79.00 & 66.96 & 78.47 & 3.75 & 0.53 \\
\hline 8 & Kyiv & 65.93 & 76.40 & 63.47 & 75.18 & 2.46 & 1.22 \\
\hline 9 & Kirovohradsk & 66.64 & 76.36 & 65.38 & 75.30 & 1.26 & 1.06 \\
\hline 10 & Lviv & 69.43 & 79.01 & 66.94 & 77.89 & 2.49 & 1.12 \\
\hline 11 & Mykolaiv & 67.49 & 76.85 & 63.77 & 74.67 & 3.72 & 2.18 \\
\hline 12 & Odesa & 67.78 & 77.17 & 64.15 & 74.15 & 3.63 & 3.02 \\
\hline 13 & Poltava & 67.6 & 76.94 & 65.98 & 75.86 & 1.62 & 1.08 \\
\hline 14 & Rivne & 68.74 & 78.11 & 64.81 & 76.96 & 3.93 & 1.15 \\
\hline 15 & Sumy & 67.91 & 77.62 & 65.83 & 76.55 & 2.08 & 1.07 \\
\hline 16 & Ternopil & 69.93 & 79.41 & 67.53 & 78.07 & 2.4 & 1.34 \\
\hline 17 & Kharkiv & 67.05 & 76.78 & 65.88 & 75.61 & 1.17 & 1.17 \\
\hline 18 & Kherson & 65.37 & 76.03 & 65.87 & 75.92 & -0.5 & 0.11 \\
\hline 19 & Khmelnitsk & 69.58 & 78.13 & 64.91 & 76.80 & 4.67 & 1.33 \\
\hline 20 & Cherkasy & 67.78 & 77.82 & 65.76 & 76.48 & 2.02 & 1.34 \\
\hline 21 & Chernivtsi & 70.25 & 78.76 & 68.96 & 78.10 & 1.29 & 0.66 \\
\hline 22 & Chernihiv & 66.05 & 76.97 & 62.26 & 75.02 & 3.79 & 1.95 \\
\hline
\end{tabular}

high indices were in inhabitants of south-eastern Poland: Podkarpackie voivodeship, Podlaskie voivodeship, Lesser Poland voivodeship, Lublin voivodeship, it being known that in all provinces, the difference in ALE indices in urban and rural population centres wasn't significant (from 0 to 2,7 years) (table 2 ).

From the above-mentioned voivodeships with high ALE indices, two of them (Podkarpackie and Lublin voivodeships) have borders with Ukraine, namely, Lviv and Volyn regions. Nevertheless, the ALE in these Ukrainian regions is considerably lower. In particular, Podkarpackie voivodeship is located practically on the border with the Lviv region, but the ALE level in urban settlements is 76.5 years in men and 83.0 years in women of Poland unlike 69.47 years in men and 78.86 years in women in Ukraine (distinction 7.03 years and 4.14 years); in rural area -74.9 years in men and 83.1 years in women unlike 67.19 years and 77.78 years, correspondingly, (distinction 7.71 years and 5.32 years). In despite of close neighborhood of regions, the average life expectancy in Poland is considerably higher than in Ukraine.

The analysis of the second determinant of social health: infant mortality has shown that during the last five years there is a significant tendency to lowering of this index in
Ukraine (for $11.4 \%$ : from 7.9 in 2015 up to 7.0 fatal cases per 1000 live-born babies in 2019), while in Poland, this index is left unchangeable (4.0 in 2015 and 3.8 fatal cases per 1000 of live-born babies in 2019) (fig. 2).

It may be connected with the fact that in Poland the infant mortality level is twice as low as in Ukraine and, for all this, the ratio is approximate within the last five years of observation.

The major distinction in infant mortality indices by gender is observed. In both countries the level of this index is much higher in boys than in girls, although the essential reduction of this distinction happens within the last 2019. So, if in 2015 in Ukraine the infant mortality level was $24.29 \%$ higher in boys, whereas in 2019 - it was only on $15.38 \%$; in Poland - on $22.22 \%$ and $8.33 \%$, correspondingly.

The next step, as a reasonable one, was considered to compare the causes of infant mortality in both countries. Due to the result of analysis it was established that in both countries in 2019 the due place in the structure of all causes of infant mortality belonged to chapter XVI in accordance to ICD-10 "Certain conditions originating in the perinatal period" $-54.39 \%$ in Ukraine and $53.05 \%$ in Poland (fig. 3). 
Table 2. Average life expectancy at birth (years) by gender and type of settlement in voivodeships of Poland in 2019

\begin{tabular}{|c|c|c|c|c|c|c|c|}
\hline & \multirow{2}{*}{ Voivodeships } & \multicolumn{2}{|c|}{ Urban settlements (C) } & \multicolumn{2}{|c|}{ Rural settlements (V) } & \multirow{2}{*}{$\begin{array}{c}\text { difference between } \\
C \text { and } V \text { in men }\end{array}$} & \multirow{2}{*}{$\begin{array}{l}\text { difference between } \\
C \text { and } V \text { in women }\end{array}$} \\
\hline & & m & f & m & f & & \\
\hline & Poland & 74.5 & 81.7 & 73.4 & 81.8 & 1.1 & -0.1 \\
\hline 1 & Lower Silesia (Dolnośląskie) & 73.7 & 81.4 & 72.7 & 81.0 & 1.0 & 0.4 \\
\hline 2 & $\begin{array}{l}\text { Kuyavian-Pomeranian } \\
\text { (Kujawsko-Pomorskie) }\end{array}$ & 74.0 & 80.9 & 73.3 & 81.1 & 0.7 & -0.2 \\
\hline 3 & Lublin (Lubelskie) & 75.1 & 82.6 & 72.9 & 82.3 & 2.2 & 0.3 \\
\hline 4 & Lubusz (Lubuskie) & 73.6 & 81.3 & 71.6 & 80.3 & 2.0 & 1.0 \\
\hline 5 & Lodz (Łódzkie) & 73.0 & 80.7 & 71.8 & 81.7 & 1.2 & -1.0 \\
\hline 6 & Lesser Poland (Małopolskie) & 75.9 & 82.7 & 74.8 & 82.7 & 1.1 & 0.0 \\
\hline 7 & Mazovian (Mazowieckie) & 75.3 & 82.3 & 72.6 & 81.7 & 2.7 & 0.6 \\
\hline 8 & Opolske (Opolskie) & 75.2 & 81.9 & 73.8 & 82.2 & 1.4 & -0.3 \\
\hline 9 & Podkarpackie (Podkarpackie) & 76.3 & 83.5 & 74.7 & 82.9 & 1.6 & 0.6 \\
\hline 10 & Podlaskie (Podlaskie) & 75.3 & 83.3 & 72.9 & 83.0 & 2.4 & 0.3 \\
\hline 11 & Pomorske (Pomorskie) & 75.5 & 82.1 & 73.5 & 80.9 & 2.0 & 1.2 \\
\hline 12 & Silesian (Śląskie) & 73.6 & 80.6 & 74.3 & 81.6 & -0.7 & -1.0 \\
\hline 13 & Swietokrzyskie (Swiętokrzyskie) & 74.7 & 82.3 & 73.0 & 82.2 & 1.7 & 0.1 \\
\hline 14 & $\begin{array}{c}\text { Varminsko-Mazurske } \\
\text { (Warmińsko-Mazurskie) }\end{array}$ & 73.7 & 81.6 & 72.0 & 80.5 & 1.7 & 1.1 \\
\hline 15 & Greater Poland (Wielkopolskie) & 74.7 & 81.8 & 73.8 & 81.2 & 0.9 & 0.6 \\
\hline 16 & $\begin{array}{l}\text { West Pomeranian } \\
\text { (Zachodniopomorskie) }\end{array}$ & 73.9 & 81.5 & 72.9 & 80.2 & 1.0 & 1.3 \\
\hline
\end{tabular}

The fourth part $(24.70 \%)$ of all deaths under 1 year old in Ukraine and one third (36.19\%) in Poland is due to "Congenital defects of development, deformation and chromosomal anomalies" (chapter XVII). Other diseases and conditions that lead to infant death, in sum, include only $20.91 \%$ in Ukraine and $10.76 \%$ in Poland. The most widespread ones are chapter XX "External causes of death" - 3rd place in Ukraine (4.48 \%) and 4th place in Poland $(2.83 \%)$ among all the causes of death under 1 year old, and chapter X "The Respiratory diseases" (4th place in Ukraine $(3.71 \%)$ and 3rd place in Poland (3.26\%)). The rarer cause of children's death under 1 year old in Ukraine were "Diseases of the Digestive system" (Chapter XI) - 0.32 \%, in Poland - "Diseases of Blood and hemopoietic organs" (Chapter III) and "Diseases of the Urogenital system" (Chapter XIV) - $0.07 \%$ each. At the same time, "Diseases of the Urogenital system" is the only chapter of diseases in Ukraine, that during the last years does not figure as the cause of children's death under 1 year old.

The comparison of infant mortality levels, in both countries, depending on the cause of death has shown that indices of practically all chapters of diseases and conditions in Ukraine are much higher than in Poland (fig. 4).

The level of index of the main causes of children's death under 1 year old that belong to chapter XVI "Certain conditions originating in the perinatal period" was in 1.9 times higher in Ukraine (38.4 cases of death per 10 thousand of live-born babies), than in Poland (20.0 cases of death per 10 thousand of live-born babies). In both countries, "The
Intrauterine hypoxia and asphyxia during labors", "The Respiratory impairment in a newborn (distress)" belonged to this chapter.

"Congenital defects of development, deformation and chromosomal anomalies" (Chapter XVII) - the second cause of death taking into account its frequency; it does not differ by the index of widespread occurrence in both countries: 17.2 cases of death per 10 thousand of live-born babies, in Poland - 13.6 cases of death per 10 thousand of live-born babies. "Congenital development defects of the heart" and "Chromosomal anomalies" were the most widespread ones in this group.

The most clearly marked distinction between the infant mortality indices in 2019 in reference to Ukraine was in group "Diseases of Blood and hemopoietic organs" (Chapter III) 18.7 times (0.5 cases of death in 10000 live-borns in Ukraine as compared to 0.03 cases of death per 10 thousand of live-borns in Poland). The essential distinction between indices was also in the following chapters of diseases: "Some Infectious and Parasitic diseases" (Chapter I) - in 15.9 times (1.7 as compared to 0.1 cases of death per 10000 live-borns, correspondingly); "Diseases of Blood circulation" (Chapter IX) - in 12.5 times (1.0 as compared to 0.08 cases of death per 10 thousand of liveborns, correspondingly); "Diseases of the Nervous system" (Chapter VI) - in 7.0 times ( 1.5 as compared to 0.2 cases of death in 10 thousand of live-borns, correspondingly). Certain peculiarities among the rates of mortality caused by the diseases of the nervous system were revealed: if in 
Ukraine, "Meningitis" was the main disease that caused death, then in Poland in addition to "Meningitis" there were "Other Degenerative diseases of the nervous system" and "Cerebral palsies and other paralytic syndromes".

In Ukraine, the single chapter of diseases which wasn't in the statistics of diseases, but led to the death of children under 1 year old - "Diseases of the Urogenital system" (Chapter XIV), in Poland it was worked out in greater detail in such subdivisions as "Diseases of the glomeruli, interstitial-canal renal diseases and other kidney ureter diseases" (N00-N19, N25-N28).

Thus, in spite of the similar climatic and geographical area, close neighborhood, Poland if we compare with Ukraine possesses many qualitative health indices which are presented by social determinants, such as average life expectancy at birth, which is much higher in Poland, and infant mortality with the indices which are half lower than those in neighboring Ukraine regardless the territorial data and gender differences. This testifies to a higher level of well-being in this country, in general, and the absence of differences in living standards between urban and rural inhabitants.

The prospect of further research is in the investigation and comparison of indices of other social determinants of health in countries-neighbors Ukraine and Poland.

\section{CONCLUSIONS}

For the purpose to ensure the persistent improvement of the quality of information which is registered when the statistical data are formed, it is necessary to promote a broad intersector teamwork inside the countries and international cooperation between the countries.

\section{REFERENCES}

1. Health 2020: the European policy for health and well-being. WHO strategy. http://www.euro.who.int/en/health-topics/health-policy/ health-2020-the-european-policy-for-health-and-well-being.

2. European Health Report 2018. http://www.euro.who.int/__data/ assets/pdf_file/0008/379862/who-ehr-2018-eng.pdf.

3. Statistical data of the State Statistics Service Of Ukraine. http://www. ukrstat.gov.ua/
4. Statistical data of the Center for Medical Statistics of the Ministry of Health of Ukraine. http://medstat.gov.ua/ukr/news.html?id=242.

5. Główny Urząd Statystyczny. http://demografia.stat.gov.pl/ bazademografia/TrwanieZycia.aspx.

6. Maksymets T., Karpyshyn N., Gutor T. et al. Influence of risk factors on insulin resistance in patients with overweight and obesity. Wiadomosci lekarskie. 2018; 71 (3 pt 1) : 558-560.

The present study is a fragment of the research project "Determinants of rural health and life expectancy" (state registration number No 0118U000099).

\section{ORCID and contributionship:}

Taras G. Gutor: 0000-0002-3754-578X ${ }^{A, F}$

Natalia I. Zaremba: 0000-0001-8185-1752 A, B, E

Oksana R. Kovalska: 0000-0001-5242-601X ${ }^{B, C, D}$

Dzvenyslava Je. Moskviak-Lesniak: 0000-0001-8238-5933 ${ }^{\text {B, }}$

Iryna M. Gerasymovych: 0000-0002-9371-7689 ${ }^{B, D}$

Oleh Ja. Kobyletskyy: 0000-0002-8399-6186 ${ }^{B, E}$

Yaryna V. Nahurna: 0000-0002-3551-6221 C, E

\section{Conflict of interest:}

The Authors declare no conflict of interest.

\section{CORRESPONDING AUTHOR}

Taras G. Gutor

Danylo Halytsky Lviv National Medical University

69 Pekarska st., 79010 Lviv, Ukraina

tel: + 380673702781

e-mail: taras_gutor@ukr.net

Received: 27.11.2020

Accepted: 11.03.2021

A - Work concept and design, B - Data collection and analysis, C - Responsibility for statistical analysis,

D-Writing the article, $\mathbf{E}$ - Critical review, $\mathbf{F}$ - Final approval of the article 